\title{
Sigarayı Bırakmada, Kitle iletişim Araçlarında Yer Alan Kamu Spotlarının Etkisi
}

\author{
Mustafa İnce ${ }^{a^{*}}$, Mevlut Can Koçak ${ }^{\mathrm{b}}$

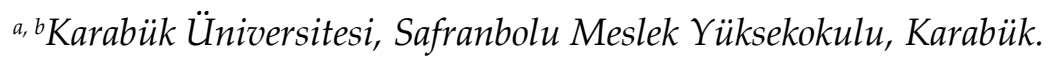

\begin{abstract}
$\ddot{O} z$
Sigara bağımlllı̆̆l hem ülkemizde hem de tüm dünyada önemli bir sorun olarak görülmektedir. Sigara, ciddi ve hatta ölümcül sağllk sorunlarına yol açmasına karşın tüketilmeye devam edilmektedir. Kadın, erkek birçok insan sigaraya bağlı olarak ortaya çıkan hastalıklarla mücadele etmektedir. Sigaranın toplum fertleri üzerindeki olumsuz etkilerinin tespitine yönelik çalışmalar da giderek artmaktadır. Bununla birlikte, sigara alışkanlığııın terk edilmesi için birçok farkl platformda bilgilendirme ve bilinçlendirme kampanyaları devam etmektedir. Bedensel, ruhsal ve ekonomik açıdan kullananları olumsuz etkileyen sigaranın sebep olduğu zararlar konusunda, toplumu bilgilendirmeye ve bilinçlendirmeye yönelik çalışmaların yapılması çok önemlidir. Ülkemizde halk sağhlı̆̆ için ciddi tehdit oluşturan sigaranın tüketimini azaltmak maksadıyla, gerek sivil toplum kuruluşları marifetiyle, gerekse devlet kurumları eliyle çeşitli çalışmalar yürütülmektedir. Bu çalışmalardan biri de kitle iletişim araçları vasıtasıyla yayınlanan kamu spotlarıdır. Bu bağlamda, sigaranın insan sağhlğı üzerinde ne gibi etkileri olduğu ve ne tür sonuçlar doğurduğu konusunda toplumun fertlerini bilinçlendirmeyi amaçlayan bu zorunlu yayınların, insanların sigara kullanma davranışlarn üzerinde tesirli olup olmadığının tespiti, bu yayınların devamı açısından önemlidir. Bu çalışma, genelde sigarayı bıraktırmaya yönelik kampanyaların, özelde ise sigara kullanımıyla ilgili kamu spotlarının, bireylerin sigara kullanma davranışları üzerinde etkili olup olmadığını belirlemeyi amaçlamaktadır. Araştırmaya göre, katılımcıların yüzde 90'ı sigarayı bıraktırma kampanyalarının insanlar üzerinde etkili olabileceğini düşünmektedir. Ayrıca çalışmaya katılanların yüzde 30'u kamu spotlarının sigara içme davranışlarn üzerinde olumlu etkisinin olduğunu belirtmişlerdir.
\end{abstract}

Anahtar Kelimeler: Sigarayı bırakma, kamu spotu, medyada kamu spotu

\section{The Impact of Public Spots on Giving up Smoking}

\begin{abstract}
Smoking addiction is seen as a major problem both in our country and all over the world. Despite cigarette causes serious health problems, it continues to be consumed. There are also increasing efforts to determine the negative effects of cigarette on the members of the society. Along with that information and awareness campaigns have been continuing on many different platforms for abandoning smoking habits. It is very important to make efforts and raise awareness to inform the public about the damages of the cigarette which negatively affect the users who use it physically, spiritually and economically. In order to reduce the consumption of cigarette, which is a serious threat to public health in our country, various activities are carried out by means of civil society organizations and government institutions. One of these works is public spots broadcast via mass media. In this context, it is important to determine whether these compulsory publications, which aim to raise awareness of the members of the community about the effects and consequences of cigarettes on human health are influential on people's smoking behavior or not. In general the aim of this study is to determine whether public spots related to cigarette quit campaigns and in particular using cigarette on influence the smoking behavior of individuals or not. According to the survey, 90 percent of participants think that smoking cessation campaigns
\end{abstract}


can have an impact on people. Additionally, 30 per cent of the respondents indicated that public spots had a positive effect on smoking behavior.

Keywords: Smoking cessation, Public spots, Public spot on the media

\section{GİRIŞ̧}

Sigara kullanma alışkanlığı sıradan ve basit bir alışkanlık değil, karmaşık bir fizyolojik bağımlılıktır. Sigara içindeki bileşenlerden bağımlılık gelişimine en fazla katkısı olan nikotindir (Rennard, 2000: 117; Aktaran: Şahbaz ve Kılıç: 2005: 98). Aksine kullananları fiziksel, sosyal, ekonomik, psikolojik vb. birçok açıdan olumsuz etkileyen çok yönlü ve ağır bir bağımlılıktır (İnce ve Koçak, 2017: 335). Üstelik sigara, sadece kullanıcısını değil, kişinin ailesini, çevresini ve hatta yaşadığı toplumu olumsuz etkilemektedir. Sigaraya başlamada küçük bir bahane yeterli iken, bağımlı olduktan sonra birakmak için profesyonel destek de dâhil birçok çaba ve girişim sonuçsuz kalabilmektedir. Dünya Sağlık Örgütü'nün bir hastalık olarak tanımladığı sigaranın uzun süre kullanılması durumunda onlarca farklı hastalığa sebep olduğu bilinmektedir.

“OECD’nin 2015 yılında yayınladığı rapora göre, Türkiye yüzde 23,8 sigara kullanım oranıyla dünyada 11. sırada yer alıyor. Rapora göre, Türkiye'de erkeklerin yüzde 37,3'ü ve kadınların yüzde 10,7'si sigara kullanıyor. Türkiye'de, her gün sigara içen kişi sayısı 10,6 milyonu erkek, 3,9 milyonu kadın olmak üzere toplam 15 milyona yakın. Ülkemizde her yıl 120 bin, her gün 300 kişi sigaraya bağlı nedenlerle ölüyor. Akciğer kanseri ölümlerinin yüzde 95'i, KOAH'a bağlı ölümlerin yüzde 90'1 sigara nedenli. Dahası kalp damar hastalıkları da yine sigaraya bağlı ölümlerin ilk sırasında geliyor. Sigara içen bir kadının akciğer kanseri olma riskinin, içmeyen bir kadına göre 1,5-3 kat daha fazla olduğu kabul ediliyor." ("Isşte Türkiye'nin sigara bağımlılı̆̆1 karnesi...", 2016) Sigara tüketiminin Türkiye'deki ekonomik boyutu da oldukça yüksek. Tütün ve Alkol Piyasası Düzenleme Kurumu (TAPDK) son beş yıllık sigara tüketimi rakamlarına göre, Türkiye'de son 5 yıl içerisinde sigara için her ay ortalama 3 milyar 996 milyon lira, günlük ise 131 milyon 371 bin liralık harcama yapılıyor.

Sigara bağımlılı̆̆ının geldiği nokta sadece ülkemizde değil dünya kamuoyunda da büyük endişeye sebep olmaktadır. Dünya Sağlık Örgütü tarafından yayınlanan, Tütün Kontrolünde Sağlık Profesyonellerinin Rolü isimli kitapçıkta, dünyada 1,3 milyar kişinin sigara içtiğinin tahmin edildiği belirtilmektedir. Aynı yayında tütün tüketimine bağlı olarak her yıl ortalama 4,9 milyon insanın öldüğü, mevcut durumun (örüntünün) devam etmesi halinde 2020 yılında çoğunluğunu gelişmekte olan ülkelerin oluşturacağı bu sayının 10 milyona yükseleceğinin tahmin edildiği belirtilmektedir. Yazının devamında başta hükümetler olmak üzere tütün karşıtı girişimlerin artırılmasının elzem olduğu belirtilmektedir.

İnsanlar arasında sigara kullanım oranları yüksek olmakla birlikte, bu oran giderek artmakta ve sigaraya başlama yaşı da düşmektedir. Buna paralel olarak sigara kaynaklı hastalığa yakalananların ve ölenlerin sayısı da her geçen gün artmaktadır. Oysa sigara bağımlılı̆̆ı ve buna bağlı olarak gelişen hastalıklar ve ölümler önlenebilir konular arasında görülmektedir. Sigara, yol açtı̆̆ı zararlardan dolayı çağımızın acilen 
çözüme kavuşturulması gereken önemli bir sorunudur. Hükümetler ve yasa koyucularla birlikte, sivil toplum kuruluşları, araştırmacılar, dernekler ve elbette bireysel çabalarla sigara kullanımı azaltılmaya çalışılmalıdır.

Sigara içen bir kişinin sağlığını koruması için yapması gereken en önemli şey sigaranın bırakılmasıdır. Sigarayı bıraktığında sigara ile ilişkili hastalıkların ortaya çıkma riski azalacak, hastalık varlığında ise hastalığın ilerleme hızı yavaşlayacaktır (Godtfredsen NS, Prescott E., 2011;5:187-94; Aktaran: Argüde vd., 2013: 82). Ülkemizde toplumsal bilinçlenme, kapalı ortamlarda sigara kullanım yasağı, ortaya çıkan hastalıklar ve ekonomik nedenlerden ötürü sigara kullanan kişilerin sigarayı bırakmak için sigara bırakma polikliniklerine başvuru sayısı günden güne artmaktadır (Argüde, ve Diğerleri 2013: 82). Başta kitle iletişim araçları olmak üzere sigaranın zararları konusunda topyekûn bir bilinçlendirme çalışması sigara kullanımının daha da azalmasına yardımcı olacaktır.

Birçok farklı fonksiyonu bulunan medyanın toplumsal yaşam, ekonomi, sanat, kültür gibi konuların yanında sağlık konusunda da bilgilendirici mesajlar ürettiği ve kamuoyu üzerinde tesirli olduğu bilinmektedir. Bütün dünyada olduğu gibi ülkemizde de pek çok insan medyayı kullanmakta, yaşamla ilgili haberleri, bilgileri öğrenmektedir. Medya, hastalıklar ve nedenleri konusunda inanları uyarma gücüne, hastalık ve tedavileri ile ilgili doğru yolları gösterebilme ve insanları yönlendirebilme yeteneğine sahiptir.

Devletin ilgili kurumları da medyanın bu özelliklerinde yararlanmak istemiştir. Bu maksatla, Sağlık Bakanlığı doğru bilgilendirme, farkındalık yaratma, tutum ve davranış geliştirme gibi temel amaçları içeren çeşitli konularda kamu spotları hazırlamıştır. Hem eğitici hem de öğretici bir nitelikte olan kamu spotları çeşitli kitle iletişim araçlarında yayınlanarak, hem toplumun çıkarlarını gözetilmiş hem de toplum, sağlıkla birebir bağlantılı konularda işbirliğine davet edilmiştir Göçmen ve Ayvaz, 2017: 127).

$\mathrm{Bu}$ çalışmanın amacı da toplumun bilgilenmesinde büyük önem arz eden kitle iletişim araçları vasıtasıyla yayınlanan kamu spotlarının insanların sigara kullanma davranışları üzerinde etkisinin boyutlarını tespit etmektir.

\section{YÖNTEM}

Kamu kurumunda çalışan kişiler üzerinde gerçekleştirilen bu araştırma, genel tarama modeline uygun olacak şekilde hazırlanmıştır; bunun yanında araştırmada, bağımlı ve bağımsız değişken arasında karşılaştırmalı ilişkisel tarama gerçekleştirilmiştir.

\subsection{Araştırmanın Uygulanması ve Örneklem Seçimi}

Kamu kurumunda çalışan kişiler üzerinde sigarayla ilgili kamu spotlarının etkisini belirlemek için bir saha çalışması gerçekleştirilmiştir. Araştırmanın evreni, çalışmanın yapıldığı zamanı kapsayan demede, Konya'da Meram ve Selçuklu ilçelerinde çalışan kamu kuruluşunda çalışan kişilerden oluşmaktadır. Araştırmada örneklem belirlenmesinde rastlantısal örnek tekniği göz önüne alınmış olup 
araştırmaya toplam 350 kişi katılmıştır. Kamu kuruluşunda çalışanlar üzerinde gerçekleştirilen bu çalışmaya konu olan veriler, katılımcılardan, yüz yüzde görüşmeye dayalı anket tekniğiyle elde edilmiştir.

\subsection{Veri Toplama Yöntemi ve Araçları}

Araştırmaya katılan kamu görevlileri üzerinde sigarayla ilgili kamu spotlarının etkisini belirlemek amacıyla 22 sorudan meydana gelen bir anket hazırlanmıştır. Bu anket formunda 5 'li Likert tipinde ( $1=$ Kesinlikle önemsiz, $5=$ Kesinlikle önemli) hazırlanan 5 soruluk bir ölçekte katılımcıların sigaranın zararları konusunda medya türlerine verilen önem düzeyi sorgulanmıştır. Araştırmada yine medyada yer alan kamu spotlarının hatırlanmasıyla ilgi olarak 5'li Likert tipinde (1= Hiç hatırlamıyorum, $5=$ Çok iyi hatırlıyorum) hazırlanan 7 sorudan oluşan bir ölçek kullanılmıştır. Medyada sigaranın zararları konusunda medyanın yeterince bilgilendirici olup olmadığını öğrenmek için de 1 ile 10 arasında 'tablo işaretleme' yönteminde dayanan bir ölçek kullanılmıştır. Bu ölçekte en düşük 1,en yüksek seviye ise 10 olarak belirlenmiştir. Çalışmanın son bölümünde ise araştırmaya katılanların sosyo-demografik özelliklerini belirlemek için hazırlanan sorulardan oluşmuştur.

\subsection{Veri Analizi ve Kullanılan Testler}

Bu araştırmanın verileri 23 Mart-22 Nisan 2016 tarihleri arasında Konya'da Meram ve Selçuklu ilçesindeki kamu kurumunda çalışan kamu görevlileri ile yüz yüze görüşme yoluyla elde edilmiştir. Çalışma sonucunda ulaşılan veriler SPSS 16 istatistik programı sayesinde elektronik ortama aktarılmıştır. Araştırmada verilerin analizinde sırasıyla; ankete katılanların demografik özellikleri ile sigaraya başlama ve sigara kullanma sürelerine ilişkin bazı bilgileri ortaya koymak amacıyla frekans analizi yapılmıştır. Çalışmada ayrıca kamu kuruluşunda çalışanların cinsiyetine göre sigaranın zararları ile ilgili konularda bilgi alamda medya türlerine verdikleri önem arasında farklılık gösterip göstermediğini Bağımız Örneklem T-Testi Testi (Independent Sample T-Test) ile hesaplanmıştır. Medyada yer alan kamu spotlarının hatırlanmasının yönünü ve gücünü tespit etmek amaciyla Korelasyon Analizine başvurulmuştur.

\section{BULGULAR ve YORUM}

Bu başlık altında öncelikle araştırmaya katılan katılımcıların çeşitli özellikleri değerlendirilmekte, daha sonra ise sosyo-demografik özellikleri ile sigaraya başlama ve sigara kullanma sürelerine ilişkin bazı bilgileri ortaya koymak amacıyla sigara alışkanlıklarına ve kamu spotlarının etkilerine ilişkin bazı bulgular ortaya konulmaktadir.

\subsection{Katılımcıların Bazı Özellikleri}

Araştırmaya katılan katılımcıların demografik özellikleri ve sigara kullanımına ilişkin bazı bulgular şu şekilde sıralanmaktadır;

Kamu kuruluşunda çalışan katılımcıların yaş dağılımının betimleyici istatistikleri incelendiğinde anket sorularını cevaplayanların yaş ortalaması 37,7 olup 
dağılımın standart sapması ise 6.78 olarak hesaplanmıştır. Ayrıca araştırmaya katılanların en düşük 22 yaşında en yüksek 57 yaşında olduğu bulgulanmıştır. Araştırmaya katılanların medeni durumlarına bakıldığında ise; yüzde 90,6 evli iken yüzde 9,4 bekârdır.

Araştırmaya katılan kamu görevlilerinin yüzde 1,7'si ilkokul mezunu, yüzde 2,3'ü ortaokul mezunu, yüzde 19,4'ü lise mezunu, yüzde $72,9^{\prime}$ u üniversite mezunu olurken, yüzde 3,7'si ise lisansüstü mezunudur.

Çalışmaya katılan kamu kuruluşunda çalışan görevlilere ne kadar zamandır sigara kullandıkları sorulmuştur. Araştırmaya katılanların yüzde 2,9'u 1 yıldan az, yüzde 4,0'1 1 ile 5 yıl arası, yüzde 11,4'ü 6 ile 10 yıl arası, yüzde 24,9'u 11 ile 15 yıl arası, yüzde 56,9'u 16 yıl ve daha fazla süredir sigara kullandıklarını belirtmişlerdir.

Katılımcılar arasında sigaraya başlama yaşı en düşük 12 iken en yüksek sigaraya başlama yaşı ise $44^{\prime}$ dür. Araştırmaya katılanların sigaraya başlama yaş ortalaması 16,98 olup, standart sapması ise 2,85'dir.

\subsection{Katılımcıların Sigaranın Zararları Konusunda Bilgi Almada Medya Türlerine Verilen Önem Düzeyi}

Araştırmanın bu kısmında katılımcıların sigaranın zararları konusunda bilgi alamda medya türlerine verdikleri önem düzeyi mercek altına alınmıştır.

Araştırmaya katılan kamu görevlileri sigaranın zararları konusunda bilgi alamda en fazla önemsedikleri medya türü 4,54 aritmetik ortalama ile internet olurken bunu sirasıly 4.02 aritmetik ortalamasıyla televizyon ile 3.88 aritmetik ortalamasıyla sosyal medya izlemektedir. Diğer bir taraftan en az önemsenen medya türü ise; 2.55 aritmetik ortalaması ile radyo olurken bunu 3.02 aritmetik ortalaması ile gazeteler izlemektedir(bkz. Tablo 1).

Tablo 1. Katılımcıların Sigaranın Zararları Konusunda Bilgi Almada Medya Türlerine Verilen Önem Düzeyinin Dağılımı

\begin{tabular}{|c|c|c|c|c|c|}
\hline $\begin{array}{c}\text { Sigaranın zararlarıyla ilgili konularda } \\
\text { bilgi almada medya türlerine verilen } \\
\text { önem düzeyi }\end{array}$ & $\mathbf{N}$ & $\sum_{1}^{N}$ & $\begin{array}{l}\text { சै } \\
\text { சَ }\end{array}$ & 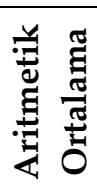 & 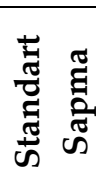 \\
\hline İnternet & 350 & 1 & 5 & 4,54 & 0,78 \\
\hline Televizyon & 350 & 1 & 5 & 4,02 & 1,14 \\
\hline Sosyal Medya & 350 & 1 & 5 & 3,88 & 0,79 \\
\hline Gazete & 350 & 1 & 5 & 3,02 & 1,19 \\
\hline Radyo & 350 & 1 & 5 & 2,55 & 1.17 \\
\hline
\end{tabular}

Çalışmada ayrıca katılımcıların cinsiyeti ile sigaranın zararları konusunda bilgi almada medya türlerine verdikleri önem düzeyleri arasında anlamlı bir farklılaşmanın olup olmadığını ortaya koymak amacıyla bağımsız örneklem T-testi (Independent Samples T-testi) uygulanmıştır. Araştırma sonuna göre katılımcıların cinsiyetine göre sigaranın zararları konusunda bilgi almada medya türlerine verilen önem düzeyi arasında anlamlı bir farklılaşma görülmemektedir. Bir diğer deyişle araştırmaya 
katılan kadınlar ve erkekler siyasal bilgilenmede medya türlerine verdikleri önem düzeyleri birbirine yakın olduğu sonucuna varılmıştır (bkz. Tablo 2).

Tablo 2. Cinsiyete Göre Katılımcıların Sigaranın Zararları Konusunda Bilgi Almada Medya Türlerine Verilen Önem Düzeyindeki Farklılık

\begin{tabular}{|c|c|c|c|c|c|}
\hline \multirow{2}{*}{ Değişkenler } & \multicolumn{2}{|c|}{ Cinsiyet } & \multirow{2}{*}{$\mathbf{t}$} & \multirow{2}{*}{ df } & \multirow{2}{*}{ Sig. } \\
\cline { 2 - 4 } & Erkek & Kadın & & & \\
\hline İnternet & 4.53 & 4.56 & -.271 & 348 & .786 \\
\hline Televizyon & 4.05 & 3.95 & .645 & 348 & .520 \\
\hline Sosyal Medya & 3.84 & 3.99 & -1.519 & 348 & .097 \\
\hline Gazete & 2.95 & 3.23 & -1.911 & 348 & .054 \\
\hline Radyo & 2.53 & 2.61 & -.601 & 348 & .574 \\
\hline
\end{tabular}

Sigaranın zararları konusunda bilgi edinmede medya türlerine verilen önem düzeyinin yönü ve düzeyini tanımlamak açısından korelasyon analizi sonuçları incelendiğinde; internet ile sosyal medya arasında $(\mathrm{r}=541 ; \mathrm{p}<.001)$ pozitif, anlamlı ve orta düzeyde bir ilişki vardır. Diğer bir ifadeyle araştırmaya katılanların sigaranın zararları konusunda bilgi edinmede medya türlerinden internete verdikleri önem düzeyi arttıkça sosyal medyaya olan güven düzeyinde de artış yaşanmaktadır. Gazete ile radyo arasında ( $\mathrm{r}=628$; $\mathrm{p}<.001)$ pozitif, anlamlı ve orta düzeyde bir ilişki vardır. Televizyon ile sosyal medya arasında $(\mathrm{r}=454 ; \mathrm{p}<.001)$ pozitif, anlamlı ve orta düzeyde bir ilişki vardır. Televizyon ile internet arasında $(\mathrm{r}=603 ; \mathrm{p}<.001)$ pozitif, anlamlı ve orta düzeyde bir ilişki vardır. Gazete ile sosyal medya arasında $(\mathrm{r}=345 ; \mathrm{p}<.001)$ pozitif, anlamlı ve zayıf bir ilişki vardır. Radyo ile sosyal medya ( $\mathrm{r}=296 ; \mathrm{p}<.001)$ arasında pozitif, anlamlı ve zayıf bir ilişki vardır. Radyo yayınları ile internet arasında ( $\mathrm{r}=192$; $\mathrm{p}<.001)$ pozitif, anlamlı ve zayıf bir ilişki vardır. İnternet ile gazete arasında ( $\mathrm{r}=204$; p<.001) pozitif, anlamlı ve zayıf bir ilişki vardır (bkz. Tablo 3).

Tablo 3. Sigaranın Zararları Konusunda Bilgi Edinmede Medya Türlerine Verilen Önem Düzeyi Sıklıklarının Korelasyon Analizi Bulguları

\begin{tabular}{|c|c|c|c|c|c|}
\hline Değişkenler & İnternet & Sosyal Medya & Televizyon & Gazete & Radyo \\
\hline İnternet & 1 & $.541^{* *}$ & $.603^{* *}$ & $.204^{* *}$ & $.192^{* *}$ \\
\hline Sosyal Medya & $.541^{* *}$ & 1 & $.454^{* *}$ & $.345^{* *}$ & $.296^{* *}$ \\
\hline Televizyon & $.603^{* *}$ & $.454^{* *}$ & 1 & .048 & $.371^{* *}$ \\
\hline Gazete & $.204^{* *}$ & $.345^{* *}$ & .048 & 1 & $.628^{* *}$ \\
\hline Radyo & $.192^{* *}$ & $.296^{* *}$ & $.371^{* *}$ & $.628^{* *}$ & 1 \\
\hline
\end{tabular}

\subsection{Katılımcıların Sigara Bıraktırma Kampanyaları ile İlgili Görüşleri}

Çalışmanın bu kısmında kamu kurumunda çalışan katılımcıların sigara bıraktırma kampanyaları hakkında görüşleri mercek altına alınmıştır.

Tablo 4'de de görüldüğü gibi katılımcıların yüzde 48,3 sigara bıraktırma kampanyalarının 'sigara bıraktırma konusunda kesinlikle olumlu' olduğunu düşünürken, bunu yüzde 42,3 'faydalı olabilir' şıkkı izlemektedir. Buna karşılık bu kampanyaların 'hiçbir faydası yok' diyenlerin oranı yüzde 8,6 iken 'herhangi bir fikrim yok' diyenlerin oranı ise yüzde $0,9^{\prime}$ dur. 
Tablo 4. Sigara Bıraktırma Kampanyaları Verilen Önem Düzeylerinin Yüzdelik Dağılımı

\begin{tabular}{|l|c|c|}
\hline \multicolumn{1}{|c|}{$\begin{array}{c}\text { Sigarayı Bıraktırma kampanyaları hakkında ne } \\
\text { düşünüyorsunuz? }\end{array}$} & $\begin{array}{c}\text { Frekans } \\
\text { (F) }\end{array}$ & $\begin{array}{c}\text { Yüzde } \\
\text { (\%) }\end{array}$ \\
\hline Sigara Bıraktırma Konusunda Kesinlikle Olumlu & 169 & 48,3 \\
\hline Faydalı Olabilir & 148 & 42,3 \\
\hline Hiçbir Faydası Yok & 30 & 8,6 \\
\hline Herhangi Bir Fikrim Yok & 3 & 0,9 \\
\hline Toplam & $\mathbf{3 5 0}$ & $\mathbf{1 0 0 , 0}$ \\
\hline
\end{tabular}

\subsection{Medyada Yer Alan Sigara İle İlgili Kamu Spotlarının Bilgilendirici ve Açıklayıcı Düzeyi}

Katılımcıların medyada yer alan sigarayla ilgili kamu spotlarını yeterince bilgilendirici ve açıklayıcı görüp görmediğini ölçmek amacıyla 1 il1 10 arasında puan vermelerine yönelik bir skala $(1=$ kesinlikle bilgilendirici ve açılayıcı değil, $10=$ kesinlikle bilgilendirici ve açıklayıcı) oluşturulmuştur. 350 kişinin verdiği yanttlar incelendiğinde, araştırmaya katılan kamu çalışanları orta düzeyde ( $\overline{x=} 5.61)$ medyada yer alan kamu spotlarını bilgilendirici ve açıklayıcı bulmaktadır (bkz. Tablo 5).

Tablo 5. Medya Yer Alan Sigara ile İlgili Kamu Spotları Yeterince Bilgilendiricimi ve Açıklayıcı Sorusunun Merkezi Eğilim İstatistikleri

\begin{tabular}{|c|c|c|c|c|c|}
\hline & N & En Az & En Çok & Ortalama & SD \\
\hline $\begin{array}{c}\text { Medyada yer alan sigarayla ilgili kamu } \\
\text { spotları yeterince bilgilendirici ve } \\
\text { açıklayıcı mı? }\end{array}$ & 350 & 1 & 10 & 5.61 & 2.61 \\
\hline
\end{tabular}

Katılımcların cinsiyeti ile medyada yer alan sigara ile ilgili kamu spotlarının yeterince bilgilendirici ve açıklayıcı sorusu arasındaki ilişkiyi tespit etmek amacıyla bağımsız örneklem T- testi uygulanmış, analiz sonuçları anlamlı bir farklılık ortaya koymuştur $(\mathrm{t}=-3.536 ; \mathrm{p}<.001)$. Kadınlar 6.44 aritmetik ortalama değeriyle erkeklere $(\overline{\mathrm{x}}=$ 5.32) oranla, medyada yet alan sigara ile ilgili kamu spotlarını yeterince bilgilendirici ve açıklayıcı bulmaktadır (bkz. Tablo 6).

Tablo 6. Cinsiyete Göre Medyada Yer Alan Sigara ile İlgili Kamu Spotlarının Bilgilendirici ve Açıklayıcı Düzeyindeki Farklılık

\begin{tabular}{|l|c|c|c|c|c|}
\hline \multicolumn{1}{|c|}{ Cinsiyet } & Ortalama & Std. Sapma & T & df & Sig. \\
\cline { 1 - 3 } Erkek & 5.32 & 2.58 & \multirow{2}{*}{-3.536} & 348 & $\mathbf{. 0 0 0}$ \\
\cline { 1 - 3 } & 6.44 & 2.51 & & & \\
\hline
\end{tabular}

\subsection{Medya'da Yer Alan Kamu Spotlarını Hatırlama Düzeyi}

Araştırmaya katılan kamu kuruluşunda çalışanların medyada yer alan kamu spotlarını hatırlama düzeylerini ortaya koymak amacıyla 5'li Likert tipinde $(1=$ Hiç hatırlamıyorum, 5 Çok iyi Hatırlıyorum) hazırlanan 7 maddeden oluşan bir ölçekten faydalanılmıştır. 
Kamu kuruluşunda çalışanların Medya'da yer alan kamu spotları arasında en fazla hatırladıkları 3,99 aritmetik ortalaması ile 'kalp sağlığı' ile ilgili kamu spotları olurken bunu sırasıyla 3,94 aritmetik ortalaması ile 'kadına şiddet' ve 3,67 aritmetik ortalaması ile 'çocuk evlilikler' izlemektedir (bkz. Tablo 7).

Tablo 7. Medya' da Yer Alan Kamu Spotlarının Hatırlamasına İlişkin Betimleyici İstatistikleri

\begin{tabular}{|l|c|c|c|c|}
\hline \multicolumn{1}{|c|}{ Değişkenler } & En Az & En Çok & Ortalama & SD \\
\hline Kalp Sağlığı & 1 & 5 & 3.99 & 1.29 \\
\hline Kadına Şiddet & 1 & 5 & 3.94 & 1.16 \\
\hline Çocuk Evlilikleri & 1 & 5 & 3.67 & 1.29 \\
\hline Obezite & 1 & 5 & 3.53 & 1.35 \\
\hline Sigara kullanımı & 1 & 5 & 3.43 & 1.37 \\
\hline SGK- Akıllı ilaç kullanımı & 1 & 5 & 2.75 & 1.43 \\
\hline Aşı & 1 & 5 & 2.51 & 1.27 \\
\hline
\end{tabular}

Çalışmada ayrıca katılımcıların cinsiyeti ile medyada yer alan kamu spotlarını hatırlamasına ilişkin anlamlı bir farklılaşmanın olup olmadığını ortaya koymak amacıyla bağımsız örneklem T-testi (Independent Samples $\mathrm{T}$ testi) uygulanmıştır. Katılımcıların cinsiyeti ile medyada yer alan kamu spotlarından biri olan çocuk evliliklerin hatırlanması arasında ( $\mathrm{t}=-3.647 ; \mathrm{p}<.001)$ anlamlı farklılaşma görülmektedir. Betimleyici istatistik sonuçları; kadınlar $(\bar{x}=4.10)$ erkeklere $(\bar{x}=3.53)$ oranla medyada çocuk evlilikleri ile ilgili olan kamu spotlarını daha çok hatırlamaktadır(bkz. Tablo 8).

Tablo 8. Cinsiyete Göre Katılımcıların Medyada Yer Alan Kamu Spotlarını Hatırlamasına İlişkin Önem Düzeyindeki Farklılık

\begin{tabular}{|l|c|c|c|c|c|}
\hline \multirow{2}{*}{ Değişkenler } & \multicolumn{2}{|c|}{$\begin{array}{c}\text { Aritmetik } \\
\text { Ortalamalar }\end{array}$} & \multirow{2}{*}{$\mathbf{t}$} & \multirow{2}{*}{ df } & \multirow{2}{*}{ Sig. } \\
\cline { 2 - 5 } & Erkek & Kadın & & & \\
\hline Aş1 & 2.48 & 2.59 & -.678 & 348 & .480 \\
\hline Kadına Şiddet & 3.96 & 3.88 & .580 & 348 & .582 \\
\hline Sigara & 3.42 & 3.43 & -.049 & 348 & .961 \\
\hline SGK-Akıllı ilaç kullanımı & 2.79 & 2.61 & 1.000 & 348 & .338 \\
\hline Çocuk Evlilikleri & 3.53 & 4.10 & -3.647 & 348 & .000 \\
\hline Obezite & 3.55 & 3.44 & .661 & 348 & .509 \\
\hline Kalp Sağlı̆̆1 & 4.01 & 3.93 & .500 & 348 & .618 \\
\hline
\end{tabular}

\subsection{Katılımcılar Üzerinde Medyada Yer Alan Kamu Spotlarının Sigara Kullanım Davranışları Üzerinde Etkileri}

Araştırmanın bu kısmında kamu kuruluşunda çalışan katılımcılar üzerinde medyada yer alan kamu spotlarının sigara davranışları üzerinde etkilisinin olup olmadığ 1 ortaya konmaya çalışılmıştır. Araştırmaya katılan sigara kullanan kamu görevlilerinin yüzde 46.'sı medyada yer alan kamu spotlarının sigara kullanım davranışı üzerinde kesinlikle etkisiz olduğunu belirtirken, yine etkisiz diyenlerin oranı ise; yüzde 21,1'dır. Diğer bir ifadeyle araştırmaya katılanların yüzde 67,1 gibi önemli 
bir kısmı medyada yer alan kamu spotlarının sigara kullanım davranışı üzerinde etkili olmadığını belirtmiştir (bkz. Tablo 9).

Tablo 9. Medyada Yer Alan Kamu Spotlarının Sigara Kullanım Davranışı Üzerinde Etkisine Yönelik Yüzdelik Dağılım

\begin{tabular}{|l|c|c|}
\hline & Frekans (F) & Yüzde (\%) \\
\hline Kesinlikle Etkisiz Oldu & 161 & 46.0 \\
\hline Etkisiz Oldu & 74 & 21.1 \\
\hline Kararsızım & 9 & 2.6 \\
\hline Etkili Oldu & 26 & 7.4 \\
\hline Çok Etkili Oldu & 80 & 22.9 \\
\hline Toplam & $\mathbf{3 5 0}$ & $\mathbf{1 0 0 , 0}$ \\
\hline
\end{tabular}

Araştırmaya katılanlar yüzde 67,4 gibi önemli bir kısmı, medyada yer alan kamu spotların korku ve kaygıya neden olmadığını belirtirken, 'evet korku ve kaygıya neden oluyor' diyenlerin oranı yüzde 32,6'dır (bkz. Tablo 10).

Tablo 10. Medyada Yer Alan Kamu Spotları Korku ve Kaygıya Neden Oluyor Mu Sorusunun Yüzdelik Dağılımı

\begin{tabular}{|l|c|c|}
\hline & Frekans (F) & Yüzde (\%) \\
\hline Evet, korku ve kaygiya neden oluyor & 114 & 32.6 \\
\hline Hayır, korku ve kaygiya neden olmuyor & 236 & 67.4 \\
\hline Toplam & $\mathbf{3 5 0}$ & $\mathbf{1 0 0 . 0}$ \\
\hline
\end{tabular}

\section{SONUÇ}

Ülkemizde son yıllarda toplumun, huzuru, refahı ve sağlığı için Türkiye Cumhuriyeti devleti tarafından ciddi çalışmalar yürütülmektedir. Özellikle sağlık alanında devrim olarak nitelendirilebilecek adımlar atılmış, yasal düzenlemeler yapılmış ve yapılmaya da devam edilmektedir. Devletin ilgili kurumları, hastalıklar ve hastalıkların önlenmesi konusunda ne kadar önemli çalışmalar yaparsa yapısın, iyi netice almak için bu tek başına yeterli olmayacaktır. Toplumun doğrudan ya da dolaylı olarak bu iyileştirme sürecine dahil olması gerekmektedir. Bu bağlamda öncelikle sağlık ve sağlığın korunması konusunda toplumun bilinçlendirilmesi büyük önem arz etmektedir. Toplumu bilgilendirmenin etkili yöntemlerinden birinin kitle iletişim araçları olduğu bilinmektedir. Ülkemizde sigarayı bırakma konusunda başta kitle iletişim araçları olmak üzere birçok farklı platformda devlet kurumları ve sivil toplum kuruluşları, farklı şekillerde halkı bilgilendirme çalışmaları yürütmektedir. Farklı konularda hazırlanan kamu spotları televizyon, radyo ve diğer kitle iletişim araçları vasıtasıyla topluma ulaştırılmaktadır. 'Sigarayı bırak, hayatı bırakma' sloganıyla sigarayı bıraktırma konulu kamu spotu, zorunlu yayın olarak kitle iletişim araçlarında yer almaktadır. Bu bağlamda ülkemizde, genelde sigarayı bıraktırmaya yönelik kampanyaların, özelde ise sigara kullanımıyla ilgili kamu spotlarının, bireylerin sigara kullanma davranışları üzerinde etkili olup olmadı̆̆ının bilinmesi, bu çalışmaların devamında strateji belirlemede önem taşımaktadır. 
$\mathrm{Bu}$ maksatla, bu çalışmada kamu kuruluşunda çalışanlar üzerinde kamu spotlarının etkisi ortaya konmaya çalışılmıştır. Bununla birlikte sigara bıraktırma kampanyalarının bireylerin sigara içme alışkanlığı üzerinde nasıl etkisi olduğunun da belirlenmesi amaçlanmıştır. Araştırmaya katılan kamu görevlilerinin, sigaraların zararları konusunda bilgi almada en fazla yararlandıkları medya türü; internet olurken, bunu sırasıyla televizyon ve sosyal medya izlemektedir. Cinsiyet açısından bakıldığında ise anlamlı bir farklılık görülmemektedir yani hem kadınların ve hem de erkeklerin sigaranın zararları konusunda bilgi edinmede tercih ettikleri medya türleri birbirine yakınlık göstermektedir.

Çalışmada ortaya çıkan başka bir sonuçta; katılımcılar medyada yer alan sigarayla ilgili kamu spotlarını orta düzeyde bilgilendirici ve açıklayıcı bulmaktadır. Cinsiyet açısından bakıldığında kadınlar medyada yer alan bu kamu spotlarını erkeklere oranla daha açıklayıcı bulmaktadırlar. Araştırma sorularına cevap veren katılımcıların önemli bir kısmı yaklaşık yüzde 90,6'sı sigarayı bıraktırma kampanyalarını olumlu görmektedir. Özellikle katılımcıların yarıya yakını kamu spotlarının sigarayı bıraktırma konusunda kesinlikle etkili olduğunu düşünmektedir. Medyada yer alan kamu spotlarının sigara kullanım davranışı üzerinde etkisiyle ilgili olarak, katılımcıların yüzde 30'u, kamu spotlarının sigara kullanma davranışları üzerinde etkili olduğunu belirtmişlerdir. Araştırmada ortaya çıkan ilginç bir sonuç ise, medyada yer alan kamu spotlarının kişiler üzerinde yüzde 67,4 oranında kaygı ve korkuya neden olmadığının belirtilmesidir.

Araştırmaya katılan kişilere medyada yer alan kamu spotlarının davranışlar üzerinde etkisi ortaya konmaya çalışılmıştır.

Araştırmanın bu kısmında kamu kuruluşunda çalışan katılımcılar üzerinde medyada yer alan kamu spotlarının sigara davranışları üzerinde etkilisinin olup olmadığ1 ortaya konmaya çalışılmıştır. Araştırmaya katılan sigara kullanan kamu görevlilerinin yüzde 46.'sı medyada yer alan kamu spotlarının sigara kullanım davranışı üzerinde kesinlikle etkisiz olduğunu belirtirken, yine etkisiz diyenlerin oranı ise; yüzde 21,1'dır. Diğer bir ifadeyle araştırmaya katılanların yüzde 67,1 gibi önemli bir kısmı medyada yer alan kamu spotlarının sigara kullanım davranışı üzerinde etkili olmadığını belirtmiştir.

Bu bilgiler 1şı̆̆ında, 'davranışlarında (olumlu) değişiklik olduğunu bildirenlerin oranının yüzde 30 olduğu' düşünüldüğünde, özellikle sigaranın zararları konusunda kamu spotlarının kitle iletişim araçları vasıtasıyla topluma iletilmesine devam edilmesi önem taşımaktadır. Bu bağlamda, kitle iletişim araçlarında yer alan mesajların tekrarlandıkça etkisinin arttığı ve daha fazla insana ulaşacağ Ayrıca mesajların izleyenler üzerinde daha etkili olmasını sağlamak amacıyla, kamu spotlarının daha ilgi çekici hale getirilmesi büyük önem arz etmektedir. Öte yandan internetin günümüzün egemen kitle iletişim aracına dönüştüğü gerçeğiyle hareket edilerek, kamu spotlarının ya da toplumsal bilgilendirme çalışmalarının internete taşınarak, internet ve sosyal medya aracılığıyla bireylere ulaştırılması gerekmektedir. 


\section{KAYNAKÇA}

Argüde, E., ve Diğerleri. (2013). Sigara Bırakma Başarısını Etkileyen Faktörler, Türk Toraks Dergi 2013; 14: 81-7

Gençoğlu, P., Bağlıtaş, H. H., ve Kuşkaya, S. (2017). Sosyal Pazarlama Aracı Olarak Kamu Spotlarının Birey Davranışları Üzerindeki Etkileri: Parametrik Olmayan İstatistiksel Bir Analiz, Uluslararası Sosyal Araştırmalar Dergisi, Cilt: 10 Sayı: 48, Şubat 2017

Godtfredsen, NS., Prescott E. (2011). Benefits of smoking cessation with focus on cardiovascular and respiratory comorbidities.Clin Respir J. 2011;5:187-94

Göçmen T. L., ve Ayvaz, S. (2017). Kamu Spotlarının Göstergebilimsel Yöntemle Çözümlenmesi: Sağlık Bakanlığı Örneği, Anadolu Üniversitesi İletişim Fakültesi Uluslararası Hakemli Dergisi, Sağlık İletişimi Sempozyumu Özel Sayısı, Cilt: 25, Sayı: 2

İlter, B., ve Bayraktaroğlu, G. (2007). “Kar Amacı Gütmeyen Sosyal İçerikli Pazarlama Uygulamaları: Sosyal Pazarlama", Erciyes Üniversitesi İktisadi ve İdari Bilimler Fakültesi Dergisi, S. 28

İnce, M. ve Koçak, M. C. (2017). Kamu Kurumlarında Çalışan Personelin Sigara Kullanma Alışkanlıkları, Turkish Studies International Periodical for the Languages, Literature and History of Turkish or Turkic Volume 12/13, p. 335-356.

İşte Türkiye'nin sigara bağımlılı̆̆ı karnesi.... (2016, Mayıs 30). Tarihinde 30 Kasım 2017, adresinden erişildi https:/www.gidahatti.com/iste-turkiyenin-sigara-bagimliligikarnesi-55462/ Türkiye'de günlük içilen sigara sayısı açıklandı. (2017, Haziran 7). Tarihinde 30 Kasım 2017, adresinden erişildi http://haber.sol.org.tr/toplum/ turkiyedegunluk-icilen-sigara-sayisi-aciklandi-199069

Rennard, S.I, Daughton, D.M. (2000). Smoking cessation. Chest, 2000; 117: 360-364.

Şahbaz, S. ve Kılıç, O. (2005). Sigara Bırakmada Kullanılan Tedavi Yöntemleri, STED, 2005, Cilt 14, Say1: 5

Türkiye İstatistik Kurumu (2016). Küresel Yetişkin Tütün Kullanım Oranları, www.tuik.gov.tr., Erişim Tarihi: 05.01.2018 